\title{
GBA2 wt Allele
}

National Cancer Institute

\section{Source}

National Cancer Institute. GBA2 wt Allele. NCI Thesaurus. Code C104425.

Human GBA2 wild-type allele is located in the vicinity of 9p13.2 and is approximately $13 \mathrm{~kb}$ in length. This allele, which encodes non-lysosomal glucosylceramidase protein, is involved in the generation and prevention of glycolipid accumulation and bile acid hydrolysis. 